\title{
A RAZÃO SUBLIME NA POLÍTICA E A SOBERANIA ENVERGONHADA DA CONSTITUIÇÃO DE 1988
}

\author{
THE SUBLIME REASON IN POLITICS AND THE ASHAMED SOVEREIGNTY OF THE \\ 1988 CONSTITUTION
}

\author{
Milton Meira do Nascimento ${ }^{1}$
}

\section{RESUMO}

O objetivo deste ensaio é apresentar uma análise da realidade política brasileira, tomando como referência a Constituição de 1988, à luz dos princípios do direito político de Jean-Jacques Rousseau. Iniciamos pelo conceito de razão sublime e avançamos para outros conceitos-chave de sua teoria política tais como pacto social, vontade geral, legislador, soberania, estado e governo. Os princípios do direito serão tomados como uma grande escala, um instrumento de medida que nos permitirá fazer a leitura da política brasileira, passando-se do dever ser para a realidade política tal como ela é. Para se chegar à conclusão de que a atividade política não pode ser definida como o embate feroz entre os grupos antagônicos, como se fosse uma guerra mortal, mas sim como um conjunto de atividades que têm como propósito maior a construção do bem comum, num terreno em que os interesses particulares se expressam entre adversários e não entre inimigos.

Palavras-chave: razão sublime, pacto social, soberania, governo, constituição

\begin{abstract}
The purpose of this paper is to present an analysis of Brazilian political reality, using the 1988 Constitution as a reference, in the light of Jean-Jacques Rousseau's principles of political law. We start with the concept of sublime reason and advance to Other key concepts in his political theory: a social pact, general will, legislator, sovereignty, state and government. The principles of law will be taken as a great scale, a measuring instrument that will allow us to understand Brazilian politics, moving from what it should be to political reality as it is. To reach the conclusion that political activity cannot be defined as a fierce clash between antagonistic groups, as if were a deadly war, but rather as a set of activities whose main purpose is to build the common good. In a terrain Where particular interests are expressed between adversaries and not between enemies.
\end{abstract}

Keywords: sublime reason, social pact, sovereignty, government, constitution

A expressão "razão sublime" aparece no texto do Contrato Social, no cap. VII do Livro II, quando Rousseau trata da figura do legislador, personagem decisivo no momento da fundação ou das reformas das comunidades políticas por intermédio da elaboração de suas leis fundamentais e

\footnotetext{
${ }^{1}$ Professor sênior do departamento de filosofia da FFLCH-USP, Com mestrado, doutorado, livre-docência e titulação pela mesma instituição e DEA pela École des Hautes Études en Sciences Sociales de Paris. Durante 6 anos exerceu o cargo de chefia do departamento de filosofia da FFLCH-USP. Foi o criador da Discurso Editorial e um dos fundadores da Associação Editorial Humanitas, além de criador e editor do Jornal de Resenhas, atividade que exerce até os dias atuais. Possui vários artigos em revistas especializadas e é autor, dentre outros livros, de “Opinião pública e revolução". Afiliação: Universidade de São Paulo - USP. Lattes:http://lattes.cnpq.br /8429886109080931. ORCID:http://orcid.org/0000-0003-1856-6240. E-mail:milton@usp.br
} 
que recorre à autoridade divina para que sua proposta de legislação tenha credibilidade. E não se trata de qualquer razão humana, a expressão é muito forte e indica que se refere à razão do legislador, isto é, o seu artifício maior de persuasão, para demostrar a todos o caráter sagrado das leis fundamentais.

A primeira questão que nos vem à mente é a de como é possível falar de razão, de racionalidade, no campo da política, dominado por paixões e jogos de interesse político-partidário. Com certeza, o campo da política é o do embate no qual os adversários procuram ganhar seus oponentes pela persuasão. Por outro lado, o domínio da racionalidade exige imparcialidade, ponderação e tantas coisas semelhantes, de tal modo que não haja espaço para contestação. A razão nos remete para o domínio da ciência, na qual as questões submetidas à prova são aceitas como válidas. Se imaginássemos que no campo da política também é possível proceder cientificamente, isto é, com discursos que, além de persuasivos, trouxessem provas de sua veracidade, de tal modo que não houvesse margem para discussões, então poderíamos afirmar com muita firmeza que teríamos o fim da atividade política. Vamos aos poucos nos enredando por um paradoxo interessante. Todos poderiam afirmar, afinal, a política não suporta a verdade? A política seria o lugar por excelência da mentira? Estamos diante talvez de um falso paradoxo, já que o tema da racionalidade na política não implica necessariamente que se abandone o recurso às certezas da ciência.

Não é disso que se trata. Reexaminemos então a figura do legislador em Rousseau para uma tentativa de elucidação dessa questão. Sua participação é decisiva no momento de fundação dos estados, ou de sua reforma, ele que conhece profundamente a natureza do povo ao qual proporá o sistema de suas leis fundamentais, mas, ao mesmo tempo, não possui nenhum interesse particular, não possui nenhuma paixão. É como se fosse uma razão pura, o que, logo de saída, não pode nos levar a confundi-lo com algum homem qualquer, por mais sábio que seja, já que todo homem é composto necessariamente de razão e paixões.

Além do conceito de razão sublime, analisaremos outros também do pensamento político de Rousseau, tais como o pacto, o povo, o soberano, o estado e o governo. Tudo isso para conduzirmos o leitor a uma análise das condições atuais da política brasileira tomando como referencial teórico os princípios do direito político do autor do Contrato Social.

Tomaremos o quadro referencial teórico de Rousseau como instrumento de verificação e precisamos dizer, desde já, que esta ferramenta não é a única, existem muitas outras também, evidentemente. Trata-se apenas de incitarmos nosso leitor a uma aventura por um caminho que nem sempre é trilhado pelos estudiosos de Rousseau e pelos estudiosos da realidade brasileira. 
Como iniciamos pela análise da figura do legislador, que preside os momentos de fundação ou reforma das comunidades políticas, no caso do Brasil, não vamos tratar dos momentos de sua fundação, mas do de sua reforma estabelecida pela Constituição de 1988.

O que é o legislador? Um homem extraordinário? Um grande sábio? Certamente não. Embora possamos ver na história várias figuras que cumpriram esse papel, como Moisés, Licurgo, Numa Pompilio e outros. Todos eles se aproximaram do modelo proposto por Rousseau. Sua função, no Contrato Social, é fundamentalmente simbólica. Ele é o espírito que preside os povos nos momentos de fundação da comunidade política ou se sua reforma. Ele é,

\begin{abstract}
"em todos os aspectos, um homem extraordinário no Estado. Se deve sê-lo por seu gênio, não o será menos por seu ofício. Não se trata de magistratura, não se trata de soberania. Esse ofício, que constitui a República, absolutamente não entra em sua constituição. É uma função particular e superior que nada tem de comum com o império humano, pois, se aquele que comanda os homens não deve comandar as leis, aquele que comanda as leis também não deve comandar os homens; de outra forma, suas leis, que são ministras de suas paixões, frequentemente não fariam mais que perpetuar as injustiças ele jamais poderia evitar que os pontos de vista particulares alterassem a santidade de sua obra" (ROUSSEAU 2020: 546).
\end{abstract}

Todo esse cuidado para que o autor das leis não seja ele também beneficiário das mesmas, com o risco de legislar em causa própria. E um outro cuidado também para tentar falar, isto é, redigir leis que os homens comuns possam entender. Donde a necessidade do recurso a uma autoridade divina. "Essa razão sublime, que se eleva para além do alcance dos homens vulgares, é aquela cujas decisões o Legislador põe na boca dos imortais, para compelir, pela autoridade divina, aqueles que a prudência humana não consegue impelir" (ROUSSEAU 2020: 548). Luiz Roberto Salinas Fortes o considerava como uma espécie de vanguarda política. Mas uma vanguarda com características especiais. Não podemos confundi-lo com as vanguardas políticas que conhecemos atualmente, como aquelas que conduziram o processo revolucionário bolchevique ou o cubano e que, uma vez concluída a revolução, continuou no comando do Estado e impôs uma nova forma de dominação. Segundo Salinas,

"O Legislador se apresenta, assim, como o veículo através do qual a razão informa a história humana. É ele o sujeito histórico por excelência, pelo menos nesta fase de instituição do corpo político, na medida em que é um representante ou substituto do corpo político, sujeito do direito. Enquanto substituto, entretanto, nenhum direito lhe pode ser conferido e sua autoridade é provisória. Ele deve desempenhar o papel característico de uma vanguarda política destinada a se suprimir, a deixar a arena histórica uma vez cumprida sua missão. Completada esta missão, os povos poderiam, a exemplo de Emílio, dizer a seus preceptores: "Reposez-vous". O Legislador surge, pois, para preencher uma lacuna, para ocupar provisoriamente um lugar que de direito pertence ao povo ideal que se trata de instituir." (SALINAS FORTES 1976: 93). 
Não é qualquer vanguarda política que está disposta a suprimir-se após o término de sua missão. Em geral todas as vanguardas continuam usufruindo das benesses das leis que ajudaram a criar. Não é o caso do legislador de Rousseau, que não possui nenhuma autoridade, nem na soberania nem no governo. Ele é tão somente o proponente da legislação fundamental, o redator das leis, que precisarão ser ratificadas pelo povo reunido.

Se investigarmos a trajetória que começa com o pacto social, isto é, o ato pelo qual "o povo é povo", o ato pelo qual a multidão se transforma numa unidade, composta por todos os membros da associação política, veremos que o que mobiliza a realização do pacto é o desejo de estar juntos. Se todos concordam em viver juntos, esta unidade constituir-se-á como um corpo político dotado de uma vontade própria que chamaremos de vontade geral. Ora, o exercício dessa vontade geral é exatamente a soberania. Quando os povos se encontram no momento de elaborar as suas leis fundamentais, eles se acham no exercício pleno de sua soberania. É neste ponto que surge a figura do legislador, uma espécie de guia que irá instruir o povo para que, ao redigir suas leis fundamentais, tome boas medidas. A instrução do legislador recai sobre a opinião pública, sobre o julgamento público. Esse processo é muito interessante, porque, dito de outra forma, aquilo que o povo quer é o seu próprio bem, mas é necessário que ele se instrua a respeito daquilo que realmente fará o seu bem. De tal modo que, nas leis fundamentais deverá estar expressa a vontade popular. Tudo aquilo que o povo quer, isto é, tudo aquilo que ele considera, que ele julga que fará o seu próprio bem deverá estar expresso nessas leis fundamentais, na sua constituição.

É importante enfatizar que, o que o povo quer, na medida em que deseja o seu próprio bem, deve estar acompanhado de um alto grau de instrução para que as decisões tomadas pela vontade geral sejam as melhores possíveis. Mesmo assim poderá haver erro, caso o julgamento não esteja bem instruído. Como vimos no texto citado de Roberto Salinas, o legislador, nesse momento da fundação ou da reforma da comunidade política, é uma espécie de substituto do povo soberano, mas não possui nenhuma autoridade soberana. Sua função é passageira, ela carrega todas as exigências de imparcialidade, sem paixões, sem interesses particulares.

No momento da fundação, as atividades políticas todas dizem respeito ao exercício da vontade geral. Aqui, a ação política será pautada pela imparcialidade, ponderação de uma razão que deve operar sem paixões. Mas isso não significa que não haverá debate. Pelo contrário, o ato de elaboração das leis envolve muita discussão, até que sejam votadas as cláusulas que farão parte da Constituição. O juiz desse jogo que se desenvolve para a elaboração das leis é o legislador, isto é, o espírito de imparcialidade que deve presidir os trabalhos. Ainda não ingressamos no campo da ação política que deve advir após a promulgação das leis fundamentais. Esta, por sua vez, terá como ponto de referência a Constituição promulgada. Os debates, as disputas, por intermédio de discursos persuasivos, entre os interesses divergentes, virão acompanhadas de acordos embora que sempre 
provisórios, para se criar uma certa estabilidade num campo minado pela luta feroz por interesses particulares. Mas o que provoca maior estabilidade neste campo é que todos os adversários deverão pautar-se pelas leis fundamentais, propostas pelo legislador e referendadas pelo povo soberano. Essas leis fundamentais ou a constituição de cada povo passam imediatamente a funcionar como o conjunto das regras do jogo político que deverão necessariamente ser respeitadas por todos os partidos sem exceção e por todas as instituições da comunidade política.

Evidentemente, a reflexão de Rousseau opera-se no plano do dever ser da vida política, no plano dos princípios do direito político. Porém, aplica-se a cada povo em particular, como um instrumento de medida. É por isso que podemos agora começar a aproximá-lo da nossa realidade brasileira. Antes disso, porém, retomemos a explicitação da ordem dos conceitos e o seu modo de funcionamento para a constituição do corpo político em Rousseau. Pelo pacto social, temos a vida do corpo político que ganha por este ato sua identidade e sua vontade própria. A seguir, os membros desse corpo começam a exercer sua vontade, a vontade geral, ou seja, começam a exercer sua soberania com o auxílio do legislador, para a criação das leis fundamentais. No âmbito desse processo estabelecem também a forma de governo que irão adotar. A partir do momento em que se colocam a tarefa da escolha do governante, ingressam no domínio da atividade política pautada pelo embate de interesses antagônicos por meio da persuasão, porém, sem perder de vista os marcos constitucionais, ou seja as regras do jogo político. O governo escolhido, por sua vez, terá a incumbência de executar as leis fundamentais, isto é, de fazer com que as leis fundamentais, de gerais que são, passem a atingir cada membro particular do estado. Este conceito assinala o processo de obediência dos mesmos indivíduos que participaram ativamente na elaboração das leis como membros do poder soberano. De elementos ativos, enquanto elaboravam as leis, passam a elementos passivos, que devem obedecer às mesmas leis que elaboraram. Tornam-se membros do estado. $\mathrm{O}$ intermediário dessa passagem, do plano geral das leis fundamentais para a particularidade de cada membro da associação política é o governo, entendido como um poder subordinado ao povo soberano, ou seja como um conjunto de funcionários do povo, que devem a este a obediência acima de tudo de acordo com os marcos constitucionais.

Com a elaboração da Constituição de 1988, o Brasil teve a oportunidade de reformular suas leis fundamentais. Os membros do Congresso Nacional que assumiram a tarefa de constituintes, conseguiram realizar um trabalho pautado pelo espírito do legislador, isto é, conseguiram incluir nas leis fundamentais uma parte considerável dos anseios do povo no período pós ditadura militar. Fizeram o que foi possível fazer dentro dos seus limites. O primeiro deles foi o de não terem convocado uma assembleia nacional constituinte independente e que fizesse a função do legislador, isto é, que, logo após o término do seu trabalho, se retirasse de campo, dando espaço aos novos governantes. Este primeiro limite por ocasião da elaboração da Constituição tirou 
também dos constituintes um certo grau de imparcialidade que poderia ser bem maior. A segunda limitação da Constituição promulgada em 1988 foi o fato de não ter sido referendada pelo voto do povo soberano. Desse modo, o grau máximo de imparcialidade do legislador exigiria, em primeiro lugar, que a Constituição fosse elaborada por um poder constituinte que deveria se retirar tão logo tivesse concluído sua tarefa e, em seguida, que o povo a referendasse, consagrando-se desse modo o exercício pleno da soberania. Mas, de qualquer modo, quando tomamos como referência os princípios do direito político do Contrato Social, as constituições reais, históricas, com toda certeza, porque realizadas por homens de carne e osso, trarão sempre um certo afastamento do ideal, que aparece no grau máximo do instrumento de medida. $\mathrm{O}$ que, evidentemente não a invalida totalmente, mas apenas assinala que ela poderia aproximar-se mais ainda do ideal. Mesmo assim, ela se apresenta como a única referência visível para que se possa imaginar que o jogo político não se fará às cegas, mas dentro de certas regras bem estabelecidas.

Seguir as regras do jogo é o mínimo que se pede a quem se aventura pela atividade política, com a certeza de que os adversários não podem ser considerados inimigos, pois, no terreno da política, quando se afirma que a guerra é a continuação da política por outros meios (Clausewitz), ou então o contrário, que a política é a continuação da guarra por outros meios (Foucault), o que se quer dizer é que a política se compara com a guerra. Ora, isto pode ocorrer com certeza, quando os atores políticos entendem a ação política como uma luta acirrada para a conquista do poder. Neste caso a luta se dá não entre adversários, mas entre inimigos e o desfecho desse processo é a rendição do inimigo e a submissão do mesmo à vontade do vencedor. Se isto pode de fato acontecer, será que a atividade política pode ser reduzida a isto, ou seja, à realidade dos fatos, ou ele encerra algo que vai para além dos fatos concretos e históricos de cada povo? Segundo Rousseau, quando definimos a regra pelos fatos concretos, por ali onde as coisas de fato acontecem, sem nenhum ponto de referência, estaremos agindo como baratas tontas, sem nenhuma referência possível, o que, evidentemente, é insuficiente para tomá-los como base para nossas definições. Por isso mesmo, não podemos dizer que a atividade política se compara com a guerra, na qual a luta é sempre por interesses particulares, das partes em conflito, mas ela se caracteriza, acima de tudo, pelo conjunto de atividades tendo em vista o bem comum. É isso que a escala dos princípios do direito político nos indica, se quisermos formar uma associação política que tenha como pressuposto a preservação da liberdade de todos os associados. pelo menos se considerarmos os dois aspectos sob os quais é preciso tratá-la. Segundo Rousseau, não podemos tratar a atividade política por aquilo que ela é na realidade dos fatos, nem somente por aquilo que ela deve ser, no plano ideal, mas por uma combinação das duas coisas, pela aproximação do plano dos princípios, tomado como instrumento de medidas, à realidade dos fatos empíricos de qualquer estado já constituído. Segundo Rousseau, a atividade política, característica por excelência dos cidadãos, possui uma peculiaridade especial 
e não pode ser comparada com a guerra, na qual o combate se dá entre inimigos. Evidentemente, na política entendida tal como ela é, de fato, isso pode ocorrer quando os contendores se apresentam no cenário político como inimigos mortais, não só dos adversários, mas também da própria constituição. Ainda no domínio dos fatos concretos, da política tal como ela é, pode ocorrer de tudo. Surgem, por exemplo, aqueles que se apresentam querendo burlar as regras do jogo ou criando para si mesmos as próprias regras. Ser contrário às regras do jogo, em política, é ser contrário à própria constituição, o que por si só já os tornaria passíveis de punição exemplar.

Se o marco constitucional é o referencial racional para o embate político, ele é também a âncora do sistema político. Neste caso, não se trata de saber se as leis fundamentais são as melhores em si, mas certamente a questão é a de saber se elas são as mais adequadas para aquele povo naquelas determinadas circunstâncias.

No nosso caso brasileiro, a Constituição de 1988 é o marco regulatório, a nossa âncora. Possui defeitos e acertos, mas é a nossa referência sem sombra de dúvidas. Por isso mesmo, todos os agentes políticos, partidos, instituições, poderes executivo, legislativo e judiciário, devem acima de tudo a ela o respeito máximo.

Durante o mandato do atual presidente da república, têm sido reiterados os atos praticados por ele que expressam nitidamente violações, ataques à Constituição. Trata-se de um poder, o executivo, que, em vez de colocar-se no seu lugar de poder subordinado ao povo soberano, colocase contra este, inverte os valores estabelecidos pelo regime democrático, no qual se reconhece, acima de tudo, o povo soberano como detentor do poder supremo. O marco regulatório da nossa constituição, além disso, se apresenta como a única certeza que o povo conseguiu estabelecer em matéria de política: pluralidade de manifestações, tolerância, liberdade religiosa, liberdade de imprensa e outras que atestam que se vive num estado democrático de direito. Esta certeza pode ser provisória, não é definitiva, mas é a que foi obtida por um certo consenso. E isto, em matéria de política já é suficiente para funcionar como regulamento das regras do jogo. Convém salientar que a atividade política, se tomarmos como parâmetro os princípios do direito político de Rousseau, se desenvolve em duas etapas bem definidas. A primeira, diz respeito ao processo de debates tendo em vista a elaboração da Constituição, processo este conduzido pelo legislador e sua razão sublime. Este é o momento da participação intensa de todos, o momento do exercício da soberania. Aqui as decisões são tomadas no sentido de se estabelecerem leis gerais. O debate cessa após a deliberação a respeito das cláusulas que serão aceitas por todos. Pode-se dizer também que este é o momento de invenção da máquina política. A seguir, a atividade política se desenvolve como atividade governamental, quando a pluralidade de visões reacende os debates tendo-se em vista a realização do que está estabelecido na Constituição. Este é o momento em que a máquina começa a funcionar, começa a andar para cumprir o seu objetivo. Sem jamais perder de vista o marco constitucional 
todos os adversários estarão imbuídos da mesma missão, que é a de executar o que foi estabelecido na Carta Magna.

Passemos agora à análise de alguns limites e algumas lacunas do nosso texto constitucional. Lemos, no Art. 1 que "A República Federativa do Brasil, formada pela união indissolúvel dos Estados e Municípios e do Distrito Federal, constitui-se em Estado Democrático de Direito e tem como fundamentos: I-a soberania; II-a cidadania; III-a dignidade da pessoa humana; IV-os valores sociais do trabalho e da livre iniciativa; V-o pluralismo político. Parágrafo único. Todo o poder emana do povo, que o exerce por meio de representantes eleitos ou diretamente, nos termos desta Constituição". Aí está a soberania como um dos fundamentos do estado democrático de direito e, logo a seguir, precisamos prestar atenção a uma sutileza, que, ao mesmo tempo em que volta a expressar a soberania popular, remete-nos para o mundo da representação, mas também para a forma direta de participação popular, isto é, de exercício da soberania. A sutileza a que nos referimos está nas expressões: "todo poder emana do povo, que o exerce por meio de representantes eleitos ou diretamente, nos termos desta Constituição". Se destacarmos o termo "diretamente", notamos que a participação direta é sempre uma possibilidade viável, porém, nunca se efetiva de fato, prenunciando um procedimento característico de algo que não deveria aparecer ali, mas que está, por assim dizer, de maneira envergonhada. A participação direta nunca ocorreu no transcurso dos últimos 33 anos de Constituição. Além disso, no seu artigo CAPÍTULO IV - Dos Direitos Políticos Art. 14, lemos que “A soberania popular será exercida pelo sufrágio universal e pelo voto direto e secreto, com valor igual para todos, e, nos termos da lei, mediante: I-plebiscito; IIreferendo; III-iniciativa popular". Ora, se a soberania popular pode ser exercida por intermédio de plebiscito referendo e iniciativa popular, podemos afirmar com toda certeza que ela não tem sido exercida em todos esses anos em absoluto. Com exceção de algumas iniciativas populares, que, aliás, tiveram que ser assumidas por parlamentares, dada a dificuldade de se aferirem todas as assinaturas, esta tem sido uma prática completamente esquecida em nossa Constituição e da qual os nossos homens públicos não tomam conhecimento. Eis aí a soberania popular envergonhada. Tanto é assim que a sequência do Artigo 14 tratará tão somente das condições de elegibilidade das pessoas. Nada é dito sobre o voto em propostas, em emendas constitucionais, em reformas da Constituição. O texto constitucional, ao mesmo tempo em que reconhece a soberania popular e explicita sua forma de exercício, muda rapidamente de assunto e começa a tratar do processo de eleição de pessoas para cargos públicos. A soberania popular permanece escondida.

Eis aí expostos os elementos que limitam ou enfraquecem a nossa Constituição, dando margem a que aventureiros se apresentem no cenário político, como o atual presidente da República, que se esmera em rasgar o texto constitucional, na ânsia de preservar seus interesses pessoais mesquinhos ou dos grupos que o apoiam. 
A política, segundo Rousseau, e a cidadania, primam, acima de tudo, pela busca constante do interesse público. As divergências político-partidárias não podem em absoluto fugir dessa busca constante do interesse público. A pluralidade dos partidos não significa que todos devam correr em busca dos seus interesses particulares. Muito pelo contrário. Será preciso sempre encontrar o denominador comum de todos esses interesses particulares que se apresentam na corrida para a conquista do interesse público.

Os aventureiros da política atuam precisamente nessa área cinzenta dos limites e das fraquezas do nosso regime constitucional. Dizer que a soberania está envergonhada em nossa Constituição é o mesmo que dizer que a democracia aí está também envergonhada, abrindo o espaço para a truculência política e para os desmandos daqueles que têm aspirações à ditadura, que fazem a apologia dos regimes autoritários e da prática da tortura. Além de agirem contra a constituição, com atitudes explícitas de defesa dos regimes autoritários, agem também como se todos os adversários fossem inimigos a abater, com a voracidade de abutres esfomeados.

É claro que dá medo imaginar que a luta política se transformou no cenário de uma luta feroz entre inimigos que precisam destruir uns aos outros, para chegarem a qualquer custo ao topo do poder político. É preciso aqui abrir parênteses para dizer que esta foi a posição de um grande número de cientistas políticos que, ao defenderem essa definição de política, tornaram-na praticamente um tabu. De tal modo que quase ninguém contesta que a política seja isso mesmo. A consequência disso é a aceitação de que em política vale tudo. E seguir as regras do jogo é apenas um faz de conta

Enquanto houver atividade política entendida como prática saudável e luta incansável pela conquista do bem público, é inadmissível tolerar práticas que se apresentem como a busca incansável do interesse mesquinho particular em detrimento do interesse de todos.

O cidadão é um membro da cidade. Cidadãos com posições diferentes, com religiões, ideologias e posições políticas divergentes, jamais poderão ser vistos como inimigos. A cidadania eleva a todos a um patamar diferenciado, porque todos estão focados no interesse da cidade, antes do interesse de cada um em particular. Entre cidadãos também não haverá lugar para trapaças. $\mathrm{O}$ jogo franco das divergências implica também na afirmação de identidades diferentes. De tal modo que, e aqui voltamos a Jean-Jacques Rousseau, quando todas as diferenças forem computadas no espaço público das comunidades políticas, então estaremos em condições de fazer valer as deliberações da vontade geral. Por isso mesmo, uma comunidade dividida por dois grandes grupos é mais nefasta do que aquela dividida por vários grupos até que se possa dizer que a grande quantidade de manifestações particulares diferentes, por mais complicado que isso possa parecer, é o caminho mais acertado para se obter a justiça política entendida como a possibilidade de participação livre nas decisões que dizem respeito a todos os membros da comunidade na busca 
pelo bem comum. Só assim, da soma das diferenças resultará afinal a possibilidade de se aferir a vontade geral. Com isso evitaríamos a formação de facções dentro do Estado, ou seja, de grupos fortemente organizados que fariam o maior esforço possível para satisfazerem os interesses do seu grupo organizado em detrimento do interesse público. Rousseau nunca evocou a unanimidade nas decisões políticas. A unanimidade só existe no momento da fundação das comunidades políticas. Trata-se da decisão primordial de se decidirem por viver juntos. Após essa decisão, e depois de terem sido elaboradas as leis fundamentais, tem início o jogo político para a execução das decisões soberanas, por intermédio da explicitação de todas as diferenças até que se chegue a acordos que, evidentemente, não serão definitivos.

A consolidação do sistema político no qual se dá preferência ou praticamente exclusividade para o voto em pessoas, em vez do voto em propostas, em emendas constitucionais, forjou no povo a convicção de que a democracia se realiza e se fortalece com a eleição de pessoas para ocuparem cargos públicos. $\mathrm{O}$ ato de votar, neste cenário, transformou-se no ato por excelência da cidadania. Evidentemente, a prática democrática precisa também do voto em pessoas, mas não pode reduzir-se a isso tão somente. O exercício da soberania popular de maneira direta, tal como previsto no texto constitucional só se consolidaria pela prática constante desse procedimento, o qual, aliás, teria o papel de educar o povo ao exercício de sua vontade livre e soberana.

Após, a promulgação do texto constitucional, quando se trata de colocar a constituição em prática, no debate que envolve a todos tendo em vista a discussão de propostas de reforma e de emendas constitucionais, entra em cena novamente a figura do legislador, já que este é quem assume a tarefa de esclarecimento, de investigação em maior profundidade para que as medidas sejam tomadas com poucas margens de erro. Com o jogo político em andamento, como identificar a atuação do legislador? Simplesmente pelo processo público de instrução para se saber quais são as melhores propostas que se apresentam para serem votadas. Note-se que estamos falando aqui de algo que está previsto no texto constitucional, mas que não ocorre em nosso caso. $\mathrm{O}$ voto para a escolha dos representantes exige que haja informações sobre a pessoa de cada um deles. Neste caso, fica bem mais difícil que cada candidato se apresente tal como é, na sua transparência, para que todos possam fazer uma boa escolha. O mais frequente é que há pouca informação detalhada sobre cada um deles, de tal modo que o voto se faz muito mais por confiança ou boa fé naqueles que acreditam na aparência do candidato, muito mais do que naquilo que de fato ele é. $\mathrm{O}$ voto em propostas é diferente. As informações sobre as propostas envolvem toda a comunidade política, sobretudo pela ação dos meios de comunicação, pela imprensa (jornais, rádio, tv, redes sociais). O espírito do legislador agora está presente em todos o s meios de comunicação, de tal modo que, quanto mais houver fontes de informação, mais bem informado estará o eleitor das propostas que se apresentarem para a deliberação 
Um outro detalhe importante, escolher representantes não é um ato de soberania popular se retomarmos aqui as expressões de Rousseau. A escolha de representantes é um ato governamental. O que indica que as decisões do povo soberano, feitas por plebiscito, referendum e iniciativa popular, seriam superiores àquelas que consistem na escolha dos representantes. Escolher representantes é um ato menor do que votar num referendum. Neste o povo exerce a soberania, no outro executa um ato governamental.

A votação em propostas de emenda constitucional (PECs) é um ato que compete ao soberano e não ao governo. O que os representantes fazem, quando votam nessas propostas é, no entanto, uma atribuição de soberania, equivocadamente executada por membros do governo. Inversão de papéis que leva o governo a ocupar o lugar do povo soberano. Tudo isso tem passado desapercebido dos responsáveis pela preservação do texto constitucional, exatamente porque, como vimos, ele encerra várias ambiguidades que se expressam naqueles limites dos quais tratamos acima neste ensaio.

Ao aplicarmos os princípios do direito político de Rousseau à realidade brasileira, tivemos que levar em consideração que, em Rousseau, os passos que vão desde a fundação das comunidades políticas ou reformas, com a elaboração das constituições até o passo seguinte que consiste na execução das leis fundamentais, foi preciso que ele recorresse a vários conceitos decisivos. Primeiramente, no ato de fundação e elaboração das leis, invocou a figura do legislador e seu papel de guia, de esclarecedor do julgamento público para que as decisões da vontade geral fossem as mais acertadas. Até aqui, todos os membros da comunidade política atuaram como membros do poder soberano. A seguir, passamos para a execução das leis fundamentais, invocandose a necessidade do governo para que essas leis chegassem a ser cumpridas pelos membros do estado considerados como pessoas particulares. Essa trajetória inscreve-se no plano do dever ser e serve como instrumento de medida, isto é, deve servir para que possamos medir o grau de afastamento e de aproximação dessa escala que ocorrem com os estados constituídos concretamente, como é o caso do estado brasileiro. É somente quando aplicamos os princípios do direito político como instrumento de medida que verificamos o quanto o estado brasileiro se conforma ou não à escala, ou então, como ele pode ser visto dentro dessa escala. Foi aí que notamos que, desde a promulgação da Constituição de 1988, a relação entre o soberano e o governo se encontram bastante descompensadas, nem tanto por aquilo que está indicado na Carta Magna, mas pelo esquecimento ou então pela ênfase que se deixou de dar ao poder soberano do povo. Como consequência, temos uma inversão de papéis: os governantes, que são parte do poder subordinado ao soberano, tomam decisões de soberania, e o soberano não funciona, encontra-se inerte, pois o povo soberano não tem sido acionado para nada. Além disso, o voto em pessoas e não em propostas 
faz com que o povo, em vez de exercer sua soberania, realiza atos de governo. Tudo isso ocorre porque a soberania popular encontra-se timidamente expressa no texto constitucional.

Em nossa carta constitucional, quais são os elementos que indicam a prática da soberania e os que apontam para a prática governamental? A soberania ali aparece como a prática de plebiscitos, referendum e iniciativa popular, que deveriam estar presentes nos momentos de decisão sobre emendas constitucionais. Sem contar, obviamente, o momento anterior que consiste na elaboração da Constituição. A atividade governamental, por sua vez, está presente em todas as demais cláusulas constitucionais que não dizem respeito às atividades de soberania. Os poderes legislativo, executivo e judiciário são instituições do aparelho governamental. O judiciário é o guardião da Constituição, no sentido de atuar para que as leis fundamentais sejam corretamente cumpridas, para dirimir dúvidas de interpretação e para o estabelecimento das penalidades decorrentes das infrações ao nosso texto maior. Cabe ao legislativo propor novas leis, reformas ao texto constitucional, porém, buscando sempre o aval do povo soberano, por intermédio de plebiscitos e referendos quando a matéria se referir a alguma reforma do texto constitucional. Sem este recurso, uma instituição governamental, que é o poder legislativo, ocupará o papel que é próprio do povo soberano. Vício que pode levar ao hábito de se considerar o Legislativo, o Congresso Nacional, como o poder soberano e não o do povo. O mesmo ocorre com os demais poderes. $\mathrm{O}$ executivo, por sua vez, pela força que possui o presidente, e pela cooptação que pode exercer sobre o poder legislativo e o judiciário, também mostra suas garras para assumir o poder soberano, fazendo do povo apenas massa de manobra para suas ações ardilosas. Já vimos anteriormente que todo poder adquirido pelos representantes é um poder de ordem governamental e não de soberania. Por isso o voto nas pessoas é também um ato governamental. Se é assim, causa estranheza que os membros do Supremo Tribunal Federal, o órgão máximo do poder judiciário, não sejam escolhidos pelo voto, tal como se dá com os outros poderes. É como se, dentre os três poderes, houvesse um que é superior. Talvez isso ocorra pelo fato de ser ele o guardião das leis fundamentais, mas não pode ser confundido com ela, evidentemente. O poder judiciário também está submetido à Constituição e lhe deve igualmente obediência irrestrita.

Todos esses limites e lacunas apontados acima têm o seu peso no equilíbrio do Estado brasileiro. Poderiam ocorrer, por exemplo, retrocessos graves decorrentes de grandes reformas do texto constitucional. Como o governo tem ocupado constantemente o lugar que cabe ao povo soberano, a Constituição corre o risco de ser alterada por ação governamental, o que é um contrassenso total. Qualquer reforma constitucional compete acima de tudo ao povo soberano.

As práticas recorrentes de substituição e de inversão de papéis no jogo político cria hábitos e expectativas não só nos homens públicos mas também dentre o povo simples que participa como espectador do grande espetáculo que se tornou a atividade política. O grande público 
acostumou-se a aplaudir e a vaiar os homens públicos, sem atentar para as suas propostas de governo. E como se tivesse havido um grande processo de educação às avessas. O povo tem sido educado não a exercer sua soberania, mas a atuar como parte da máquina governamental que tem sede de voto para alimentar sua pretensa soberania, uma soberania usurpada. Com o passar dos anos o povo se esquece de que, na democracia, ele é o soberano e entra na dança das grandes campanhas eleitorais, nas quais os candidatos são as figuras principais, os grandes atores do espetáculo político. Nesse cenário, nenhuma ou pouquíssimas palavras sobre grandes propostas ou projetos de longo prazo para o país. Todos estão concentrados no desempenho dos candidatos, à espera do grande ator que virá tirar o povo da miséria, que irá acabar com a corrupção, que trará leite e mel para a mesa dos brasileiros. Esta cultura política está arraigada na mentalidade moderna dos brasileiros. Resta saber como é possível começar a injetar aí alguma luz no sentido de fazer com que o povo recupere a sua soberania usurpada.

Em geral, muitas críticas endereçadas à teoria política de Rousseau veem nela algo de totalmente inalcançável, impossível de realizar-se. Ou então, quando tentarem realizá-la será sempre em detrimento da liberdade e a favor da dominação da maioria. Muitos pensam que Rousseau propõe uma democracia direta. O que também seria impraticável. Pedir que o povo recupere a sua soberania não é pedir que se instaure uma democracia direta. Mesmo porque a participação direta nas decisões que dizem respeito à soberania é algo bastante diferente da participação direta na instância governamental, como seria o caso da instauração de uma democracia direta. O povo pode participar direta e intensamente dos debates para a elaboração de suas leis fundamentais e nos momentos de reforma ou de emendas à Constituição e, ao mesmo tempo, ter, na esfera governamental, seus representantes eleitos para cumprirem cargos de administração.

A participação direta na soberania não se confunde também com a participação do povo em manifestações massivas. Quando o povo vai às ruas ele o faz para reivindicar algo ou para pressionar os membros dos poderes públicos. Mas este procedimento se apresenta fora das instituições políticas consolidadas no aparato do Estado democrático. A participação do povo nas ruas ocorre por insatisfação popular, para demonstrar que alguma coisa não está bem na condução das questões que dizem respeito à vida pública do país.

O povo nas ruas, a força dos meios de comunicação, tudo isso funciona como processo de vigilância sobre os homens públicos, como mobilização da opinião pública, como alerta dos legisladores para indicarem que algo precisa ser alterado. Mas tanto a mídia quanto o povo nas ruas não se inscrevem no quadro institucional das organizações responsáveis pelo funcionamento da máquina estatal. No entanto, essa força que, aparentemente está fora das instituições, muitas vezes possui um papel decisivo. Trata-se de um sinal de alerta, de perigo, de risco para a estabilidade do 
estado. Os atos públicos a favor e contra os governos estabelecidos fazem parte do sistema democrático e se inscrevem no quadro das liberdades de manifestação e expressão. Atos que às vezes podem transbordar e provocar quedas de governos ou retrocessos políticos consideráveis. As massas que vão às ruas agem de acordo com o seu julgamento. E são facilmente influenciadas pelos meios de comunicação, notadamente, na contemporaneidade, pelas redes sociais. Há algum tempo atrás, todos sabiam de onde provinha a informação, os meios de comunicação poderiam ser facilmente identificados e suas mensagens bastante conhecidas. Atualmente, a informação vem de múltiplos lugares nem sempre identificados e conhecidos. As informações verdadeiras e falsas circulam no mesmo espaço, de tal modo que se instaura um imenso emaranhado no qual será necessário um grande esforço para se localizar corretamente em relação a elas. Seu efeito é imediato sobre as massas. A velocidade de informações falsas e verdadeiras é estonteante.

A mobilização da opinião pública que antes se fazia pelos chamados "formadores de opinião", agora se faz com muito mais intensidade pelas redes sociais, nas quais os antes conhecidos por "formadores" se transformaram em "influenciadores digitais" e os que a eles aderem são os "seguidores". Neste quadro, nota-se que, em vez da instrução, ocorre um processo bem raso de doutrinação em todos os terrenos, mas no nosso caso, de doutrinação política. Quase não há tempo para a reflexão a respeito do que diz o influenciador. Trata-se ou de segui-lo ou de recusá-lo. Como utilizar esse meio para um debate sério sobre a realidade política brasileira? Como dizer, pelas redes sociais, que o povo brasileiro precisa recuperar a sua soberania? E não só isso, como fazer com que as mídias tradicionais recuperem sua força de instrução se todas elas se utilizam dos mesmos recursos das redes sociais? Pode a Internet nos fornecer meios modernos de participação intensa da população nos negócios públicos? Não ficou mais fácil para todos participarem de decisões públicas pela utilização de mecanismos de votação em rede?

Pois bem, as mesmas redes que mobilizam o povo a ir às ruas precisaria mobilizá-lo também a exercer a sua soberania. Resta, então, a organização desse processo em termos institucionais.

$\mathrm{Na}$ abertura deste artigo havíamos levantado a questão da verdade na política, entendendose este processo como a possibilidade de a política funcionar por intermédio de verdades inquestionáveis e, desse modo, afastando-se inteiramente da mentira. Mas se pensarmos como Hannah Arendt de que pensar numa verdade que se imponha a todos sem que haja nenhuma forma de contestação é colocar-se de fora da política, então veremos que a atividade política é mais complexa do que se imagina. Ora, o ingresso da verdade na política, entendido pelo viés da figura do legislador de Rousseau é um processo muito peculiar, pois, para se saber qual lei convém a cada povo em particular, será preciso que o próprio povo se instrua a respeito da sua própria realidade. Tal instrução, evidentemente, provém de alguma fonte que indica, que aponta que algo precisa ser 
feito em razão de algum motivo plausível. No entanto, muitas vozes falarão ao mesmo tempo, porém, sempre com o intuito de estarem expressando situações, condições verdadeiras de acordo com a sensibilidade de cada segmento da população. Os sentimentos que se expressam pelas múltiplas vozes podem ser muitas vezes conflitantes. E com muita frequência será difícil encontrar acordo entre eles. O que faz o legislador nesses casos? Simplesmente opera no sentido de que tais sentimentos sejam os mais autênticos possíveis, que se expressem na sua verdade, isto é, na sua transparência. No entanto, são sempre verdades particulares, expressas por indivíduos ou grupos, e isso é suficiente para que participem nas deliberações, isto é, para que exerçam sua soberania. Ocorre que os indivíduos e grupos mal-informados farão julgamentos equivocados, ao passo que os bem-informados farão bons julgamentos e tomarão decisões mais justas. Como são múltiplos os indivíduos e os grupos, as verdades também serão múltiplas e particulares, válidas primeiramente para cada um deles. Será apenas o consenso dará a elas a possibilidade de aparecerem como válidas para todos ou para o maior número de pessoas. É nesse sentido que em matéria de política não é possível pautar-se por uma verdade inquestionável previamente concebida. A "verdade" que se extrai após um longo debate será sempre resultado de um acordo consensual e, além disso, será sempre provisória, jamais definitiva. Grupos e indivíduos que se apresentam com falsidades e mentiras, deliberadas ou não, irão se expressar sempre no cenário político e entrarão em confronto com aqueles que terão a oportunidade de desmenti-los.

A verdade que o legislador representa, e que ele procura transmitir por intermédio da persuasão e recorrendo à ajuda da razão sublime, também não é uma verdade absoluta, não é a última palavra em matéria de política. Ela é tão somente aquela verdade que melhor expressa as condições de um povo num determinado momento de sua história. A nossa Constituição de 1988 não é uma verdade absoluta, mas é a que expressou a vontade pública num determinado momento da história do povo brasileiro.

Por outro lado, quando a atividade política passa a ser a de indivíduos e grupos que se apresentam como portadores de verdades absolutas, de caráter ideológico ou religioso, aí sim, eles estarão no caminho da destruição completa da vida política. É o caso daqueles que enxergam a política como uma guerra entre inimigos. É como aqueles torcedores de futebol que querem ver a morte dos seus adversários. Após a destruição de todos eles, não terão mais com quem jogar. Fim de jogo. Fim da política.

\section{REFERÊNCIAS BIBLIOGRÁFICAS:}

ARENDT, Hannah, Entre o passado e o futuro, São Paulo, Ed. Perspectiva, 1972. 
CLAUSEWITZ, C. von, On war, trad. Michael Howard e Peter Paret. Princeton, Nova Jersey: Princeton University Press, 1984.

FOUCAULT, Michel, Em defesa da sociedade - Curso no Collège de France (1975-1976), São Paulo, Martins Fontes, 2002.

NASCIMENTO, Milton Meira, A farsa da representação política, São Paulo, Discurso Editorial, 2016.

Opinião pública e revolução, São Paulo, Discurso Editorial, 2a edição, 2016.

ROUSSEAU, Jean-Jacques, Escritos sobre a política e as artes, Pedro Paulo Pimenta (Org.) Brasília e São Paulo, Editora da UnB e UBU, 2020.

SALINAS FORTES, Luiz Roberto, Rousseau, da teoria à prática, São Paulo, Editora Ática, 1976.

Trabalho recebido em 02 de outubro de 2021

Aceito em 31 de outubro de 2021 